\title{
Studies for Intramolecular Ring Closure of Amino Vinyl Epoxides. Stereoselective Synthesis of Piperidine and Pyrrolidine Systems
}

\author{
Jae Du Ha,,$"$ Eun Young Shin,,$+\neq$ Yongseog Chung,,$" *$ and Joong-Kwon Choi \\ "Medicinal Science Division. Korea Research Instinte of Chemical Technolog: Daejeon 305-600. Korea \\ "Department of Chemistry, Chunghuk National University. 48 Gaesin-dong, Cheongit 361-763. Korea \\ Recened July 212003
}

Key Words : Piperidine, Pyrrolidine, Ring closure, Vinyl epoxide, Endo and exo mode

Hydroxylated piperidine or pyrrolidine systems are indeed a useful building block for the nucleus present in several major classes of pyrrolizidine, indolizidine, and quinolizidine alkaloids.' One most reliable methodology to access those systems is a regio- and stereoselective ring closure of epoxides by internal nitrogen nucleophile. According to Baldwin rules, ${ }^{2}$ ring closure of epoxides generally proceeds via the favored 5 -exo mode rather than the 6-endo mode as shown in Scheme 1. ln order to reverse this tendency, the introduction of vinyl group adjacent to epoxide is one of the widely employed methods. ${ }^{34}$ In contrast to the numerous reports ${ }^{3}$ for the ring closure of vinyl epoxides with the intemal oxygen nucleophile, there have been only handful examplest in the intramolecular ring closure of vinyl epoxides by nitrogen nucleophiles. Moreover, to our best knowledge, there has been no report for acid-induced ring closure of vinyl epoxides with deactivated nitrogen nucleophiles, e.g. protected by Cbz group.

Herein we wish to report our results of the ring closure of a number of vinyl epoxides under acidic conditions and its application to the synthesis of alkaloids. In order to explore the scope of the ring closure of the vinyl epoxides, we synthesized various substrates from the corresponding $N$ Cbz protected aminoalcohols as shown in Scheme 2. Swem oxidation of the alcoliols Ia-c and subsequent HornerWadsworth-Emmons olefination of aldehydes using $\mathrm{I} i \mathrm{OH}$. triethyl 4-phosphonocrotonate, and $4 \AA$-MS 5 furnished the $(E, E)$-dienoates 2 a-c in $73-80 \%$ yields. Regioselective epoxidation of 2a-c using mCPBA and $\mathrm{Na}_{2} \mathrm{HPO}_{4}{ }^{6}$ afforded the desired amino epoxy alkenes 3a-c in $80-93 \%$ yields. To obtain the epoxy dibromoalkene 6. Swern oxidation of $\mathbf{1 b}$. followed by Wittig olefination $\left(\mathrm{PPh}_{3}=\mathrm{CHCO}_{2} \Gamma \mathrm{t}\right)$ afforded the unsaturated ester 4 in $68 \%$ overall yield. DIBAI, reduction and subsequent epoxidation using mCPBA gave the epoxy alcohol 5 in $68 \%$ overall yield, which was oxidized with $\mathrm{SO}_{3}$ pyr complex and subsequent dibromoolefination $\left(\mathrm{CBr}_{4}, \mathrm{PPh}_{5}\right)^{\bar{\gamma}}$ to afford the epoxy dibromoolefin 6 in $55 \%$ overall yield.

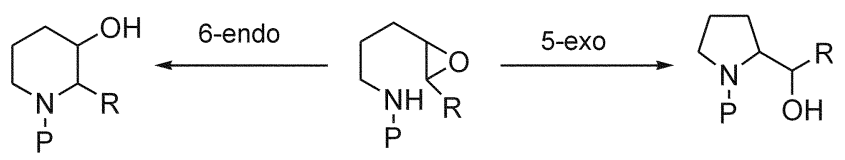

Scheme 1

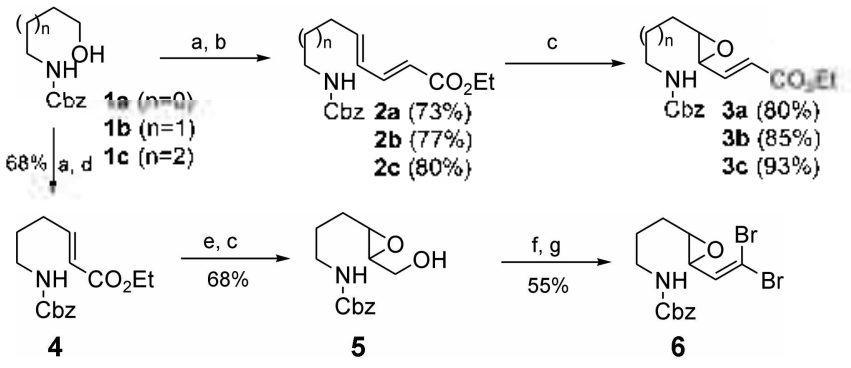

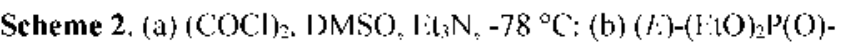
$\mathrm{Cl}_{2} \mathrm{Cll}=\mathrm{CHCO} \mathrm{L}_{2} \mathrm{~L}$. LiOH, 4 A-MS. IIIF, rellux: (c) mC.PBA. $\mathrm{Na}_{2} \mathrm{HPO}_{4}$. $\mathrm{CH}_{2} \mathrm{Cl}_{2}$. r.t: (d) $\left.\mathrm{PPh}_{3}=\mathrm{CHCO}\right)_{2}$ Et benzene. ruflux: (c) DIBAL. $\mathrm{C}_{2} \mathrm{Cl}_{2},-78^{\circ} \mathrm{C}$; (f) $\mathrm{SO}_{3}$ pytidine. $\mathrm{CH}_{2} \mathrm{Cl}_{2}$ : DMSO (4: 1 ); (g) $\mathrm{PPl}_{1.3}, \mathrm{Cl}^{\circ} \mathrm{r}_{4}, \mathrm{Cll}_{2} \mathrm{Cl}_{2} 0^{\circ} \mathrm{C}$.

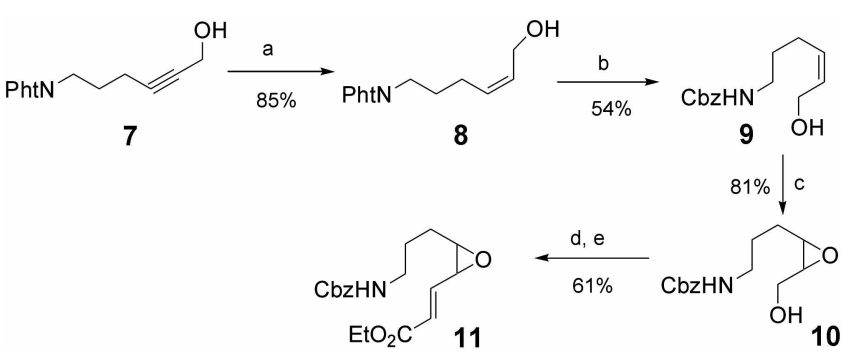

Scheme 3. (a) $10 \%$-Pd- $\mathrm{Ca}^{2} \mathrm{OO}_{3}$, quinoline: (b) i) $\mathrm{NI}_{2} \mathrm{NI}_{2} \cdot \mathrm{I}_{2} \mathrm{O}$. Et(OH. reflux. ii) (bzCl. $\mathrm{Na}_{2} \mathrm{CO}$. THF : $\mathrm{H}_{2} \mathrm{O}$ (5: 1$)$ : (c) mCPBA. $\mathrm{Na}_{2} \mathrm{HPO}_{4} . \mathrm{CH}_{2} \mathrm{Cl}_{2}$, r.t: (d) $\mathrm{SO}$; pyridine. $\mathrm{CH}_{2} \mathrm{Cl}_{2}$ : DMSO (4: 1).

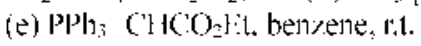

Partial reduction of 7 in the presence of L indlar catalyst and quinoline furnished the $(Z)$-olefin 8 in $85 \%$ yield, which was then subjected to dephthaloylation using excess $\mathrm{NH}_{2} \mathrm{NH}_{2}$ and subsequent $\mathrm{Cb}$. protection reaction to afford 9 in $54 \%$ yield. Fpoxidation of 9 afforded the epoxy alcohol $10(81 \%)$, which was transformed to the vinyl cis-epoxide 11 by oxidation ( $\mathrm{SO}_{3}$ pyr complex) and Wittig olefination $\left(\mathrm{PPh}_{\S}=\right.$ $\mathrm{CHCO}_{2} \Gamma \mathrm{t}$ ) in $61 \%$ yield.

Our initial task was to find an active acid system in the intramolecular ring closure (Table 1). Thus, the trans-epoxide 3 b was treated with various acids $(0.1$ eq. $)$, such as $7 . \mathrm{nCl}_{2}$, $\mathrm{Cu}(\mathrm{OTf})_{2}, \mathrm{MgBr}_{2}, \mathrm{CuBr}_{2}, \mathrm{liClO}_{4}, \mathrm{BF}_{3} \cdot \mathrm{OF}_{2}$, and camphorsulfonic acid (CSA), in methylene chloride at $0^{\circ} \mathrm{C}$. $\mathrm{Cu}(\mathrm{OTf})_{2}$ gives very little cyclized products $(<5 \%)$ and $\mathrm{MgBr}_{2}(1 \mathrm{eq}$.) resulted in undesired side reaction to give trans- $\gamma$ bromo- $\delta$-hydroxy- $\alpha, \beta$-unsatutrated ester (structure not shown) in $89 \%$ yield, which was generated by attack of 
Table 1. $\mathrm{BF}_{3} \cdot \mathrm{OEt}_{2}$ Induced Ring Closure of Vinyl Epoxides ${ }^{a}$

\begin{tabular}{|c|c|c|}
\hline Entry & Product & Yield (\%) \\
\hline 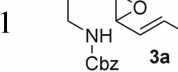 & & $80 \%$ \\
\hline $\mathrm{Cbz} \quad 3 \mathrm{~b}$ & $\begin{array}{cc}\mathrm{CO}_{2} \mathrm{Et} & \mathrm{N} \\
\mathrm{Cbz}\end{array}$ & $\begin{array}{c}86 \% \\
(44: 56)\end{array}$ \\
\hline 3 & & NR \\
\hline 4 & & $69 \%$ \\
\hline $5 \sum_{\mathrm{CbzHN}} 1$ & $\mathrm{CbZ} \overline{\mathrm{O}} \mathrm{H}$ & $85 \%$ \\
\hline
\end{tabular}

a Reaction condition: $\mathrm{BF}_{3} \cdot \mathrm{OEt}_{2}(1 \mathrm{eq}), 0 \rightarrow 25^{\circ} \mathrm{C}, \mathrm{CH}_{2} \mathrm{Cl}_{2}, 10-30 \mathrm{~min}$.

${ }^{b}$ Starting material was recovered. ${ }^{c}-20 \rightarrow 0{ }^{\circ} \mathrm{C}$

bromide anion to an epoxide. Camphorsulfonic acid was effective $(77 \%)$, however stoichiometric amount of $\mathrm{BF}_{3} \mathrm{OEt}$. at $0^{\circ} \mathrm{C}$ in $\mathrm{CH}_{2} \mathrm{Cl}_{2}$ produced the best results, affording a ca. $44: 56$ mixture of 6-endo and 5-exo products, $13^{\circ}$ and 14 , in $86 \%$ combined yield. A catalytic amount of $\mathrm{BF}_{3} \mathrm{OEt}_{2}$ also worked, but the reaction was not completed even after prolonged reaction time. Although the cyclization proceeded in a highly stereoselective manner, the reaction suffered from low regioselectivity, primarily due to the electrondeficient double bond. However, dibromovinyl epoxide 6 exclusively produced the 6-endo product 15 due to the higher electron density of double bond compared to $\mathbf{3 b}$. Ring closure of the lower homologue $\mathbf{3 a}$ furnished only the pyrrolidine product 12 in $80 \%$ yield as expected. For the ring closure of the 7-membered ring precursor 3c. we were not able to detect any trace of 6-exo or 7-endo product and the starting material was recovered intact. [his observation was in sharp contrast to our prediction that the reaction of $\mathbf{3 c}$ would produce the cyclized products according to the way as shown in Nicolaous example: the cyclization of hydroxy epoxide (hydroxy group in place of $\mathrm{NHCbz}$ of $3 \mathbf{c}$ ) using camphorsulfonic acid gave a mixture of 6-exo and 7-endo products $(\mathrm{ca} .4: 1) .^{\text {ith }}$ It could be suspected that the cyclization of 3c might be hampered by unfavorable geometric conformations according to Baldwin rules as well as a weak nucleophilicity of deactivated nitrogen atom compared to hydroxy group. Under the same conditions utilized for the trans-epoxide, the cis-isomer $\mathbf{1 1}$ led exclusively to the 5-exo product 16 as a sole product in $85 \%$ yield. This is likely due to the configuration of the cis-epoxide to be disfavored the 6 endo ring closure despite the presence of the vinyl group. ${ }^{3 a}$

The structure of cyclized product was determined by careful analysis of spectral data. Decoupling experiments of 13 revealed the $\mathrm{H}-2$ proton at $\delta 5.01$ as broad singlet when vinyl proton was irradiated, indicating no coupling (or small coupling constant) with the $\mathrm{H}-3\left(J_{2.3}=0\right)$, thereby both the $\mathrm{C}-2$ and $\mathrm{C}-3$ substituents might be oriented in pseudoaxial position. The ultimate stereochemical assignment of 13 was

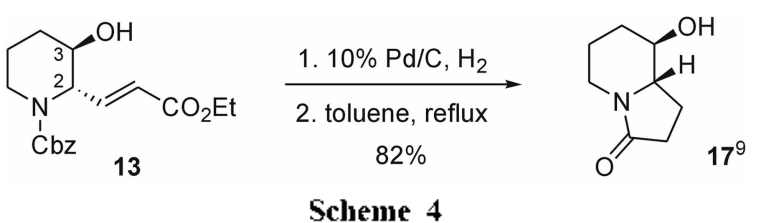

unequivocally confirmed by conversion to known indolizidinone derivative. ${ }^{10}$ Hydrogenolysis of $\mathbf{1 3}$ and subsequent heating in toluene cleanly gave the indolizidinone $17^{9}$ in $85 \%$ yield. It is noteworthy that the corresponding indolizidinone derivative would be readily converted to swainsonine and its analogues by the known procedure. ${ }^{10 \mathrm{~b}}$

In summary, we described the exploitation of the ring closure of vinyl epoxides with internal nitrogen nucleophile under acidic condition leading to piperidine and pyrrolidine systems. This method should be of general synthetic utility in the stereoselective synthesis of quinolizidines, indolizidines, and related aza-heterocycles.

Acknowledgment. We thank professor Yeun-Min Tsai, National Taiwan University for providing spectral data of indolizidinone $\mathbf{1 7 .}$

\section{References}

1. For reviews on alkaloids. see: (a) 'Takallata. [l.; Vomose. T. The Athuloids 1993. 44. 189. (h) [3urgess. K.: I lenderson]. L. Fetrathedron 1992. 48. 4045. (c) Nishimura. Y. In Situdies in Naturd Prodicts Chenistry: Atta-ur-Rahtmatl. Ed.: Elsevier: Amsterdam. 1992: Vol. 10. p 495. (d) Vemr. A. E. Tetrahedom 2000. 56.8579

2. Batdwin. J. T. . C. Chem. Soc., (hem. Commun. 1976. 734 .

3. (a) Nicolaou, K. C.. Prasald C. V. C.. Soners, P. K.: I Iwang C.-K. J. An. (hem. Soc. 1989. ///. 5330. (h) Nicolaou K. C.: Prasad. C. V. C.: Soners. l'. K.: Hwang. C.-K. J. An. Chem. Soc. 1989. ///. 5335. (c) Matsukura. H.: Morimoto. M.: Koshito. H.: Nakata. T. Tetrothedron lett, 1997, 38. 5545. (d) Suzuki. T.: Sato. O.: I Iirama. M. Tetritiedron I.ett, 1990, 3/, 4747.

4. (a) Asabka. M.: Ohkura $N_{\text {: }}$ Yokota. M.: Sonoda S.: Takei. H. Heterocytes 1994. 38. 2455. (b) Trost. 13. M.: Romero, A. (j. J. Org. Chem 1986. 51. 2332. (c) Mukai. C.: Suginoto. Y-i.: Misazawa. K.: Yamaguchi. S.: Hastaoka. M. J. Org. Chem. 1998. 63. 6281 and references cited therein.

5. Takaces. J. M.: Jaber. M. R.: (Jement. F: Walters. C. J. Org. (hem. 1998. 63.6757.

6. (a) IIchida K.: Watanalse. I1.: Kitahara T. Heteroctedes 2000. 53. 539. (b) Gong. Y.-D.: Yoo. S.-E. Bhll. Norean Chem. Soc. 2001. 29.941.

7. Corcy. E. I.: Fuchs. P. L. Tetrahedron Lett. 1972. 13. 3769.

8. Danishetsky, S.: McKec. R.: Singh. R. K. J. Im. (hem. Soc, 1977. 99. 4783 .

9. Selected spectroscopic data for 13 : 'I I NMR (300 MIL.. C.IXC $\left.l_{3}\right) \delta$ 1.29 (t. $3 \mathrm{H} . J$ 7.1 Hz). $1.43-2.00$ (m. $4 \mathrm{H}$ ). 2.94 (dt. $1 \mathrm{H.} J 3.0$. $13.3 \mathrm{~Hz}$. 4.04 (m. 1H). 4.13 (m. IH). 4.20 (q. $2 \mathrm{H} . J=7.1 \mathrm{~Hz}$. 5.01 (m. IH). 5.15 (s. $2 \mathrm{H}$ ). 5.87 (dd. $1 \mathrm{H} . J=2.2 .15 .9 \mathrm{~Hz}$ ). 6.82 (dd. $1 \mathrm{H}, J=4.3 .15 .9$ [lo $), 7.32(\mathrm{~m}, 5 \mathrm{H}):{ }^{13} \mathrm{C}$ NMR $(90 \mathrm{MH} / \mathrm{l}$. CDCl $)_{3} \delta$ 14.6. 19.0. 27.1. 40.3. 59.2. 61.1. 67.9. 67.9. 123.7. 128.2. 128.5. 128.9. 136.8. 143.2. 156.9. 166.3. Jor 17: 'H NMR (300 MHz. CLC. $) \delta 1.35-1.53$ (m. 3H). 1.71-1.96 (m. 2H). 2.09 $2.12(\mathrm{~m} .1 \mathrm{H}) .2 .29-2.42$ (m. $3 \mathrm{H}) .2 .56(\mathrm{td} . J=12.5 \mathrm{~Hz} .3 .4 \mathrm{~Hz}$. IH). 2.70 (s. 1H). $3.16-3.29$ (m. $2 \mathrm{H}$ ). 4.03 (dd. $J=3.5 \mathrm{~Hz}$. IH): $\left.\left.{ }^{13} \mathrm{C}, \mathrm{NMR}(90) \mathrm{Ml} 17 . \mathrm{CDC}\right]_{3}\right) \delta 22.7,23.7 .30 .6,33.8,39.7 .63 .2$. 73.6. 174.3

10. (a) Tsaid. Y.-M. J. Chem. Soc., Chem. Commun. 1996. 2469. (b) Oishi. J.: Iwahuma. I: Hirama. M.: Ito. S. Sinlet 1995. 404. 